\title{
The influence of catch-and-release on mortality of Salminus brasiliensis (Cuvier, 1816)
}

\author{
R. A. K. Sanches ${ }^{a *}$ (D) and P. A. Piana ${ }^{b}$ \\ aPrograma de Pós-graduação em Recursos Pesqueiros e Engenharia de Pesca - PREP, Universidade Estadual do Oeste de \\ Paraná - UNIOESTE, Campus de Toledo, Rua da Faculdade, 645, Jardim La Salle, CEP 85903-000, Toledo, PR, Brasil \\ bPrograma de Pós-graduação em Recursos Pesqueiros e Engenharia de Pesca - PREP, Grupo de Pesquisas em Recursos \\ Pesqueiros e Limnologia - GERPEL, Instituto Neotropical de Pesquisas Ambientais - INEO, Rua da Faculdade, 645, \\ Jardim La Salle, CEP 85903-000, Toledo, PR, Brasil \\ *e-mail: raksanches@hotmail.com
}

Received: June 18, 2018 - Accepted: August 8, 2019 - Distributed: November 30, 2020

(With 3 figures)

\begin{abstract}
Catch-and-release (CR) angling has been used to assist management programs seeking to promote the conservation and recovery of some recreational fish stocks by decreasing mortality from fishing. However, without appropriate fish handling, this activity may cause damage and injuries to individual fish, causing mortality. Therefore, CR should be allowed under some circumstances that ensure higher rates of survival to achieve the goals of the conservation measures. Thus, we experimentally tested the CR effects on dourado (Salminus brasiliensis) by comparing caught-and-released fish (CR fish) with uncaught fish (control fish) in a pond and estimating individual mortality rates related to seven air exposure times (AET: 120 s, 240 s, 360 s, $480 \mathrm{~s}, 600 \mathrm{~s}, 720 \mathrm{~s}$ and $840 \mathrm{~s}$ ). We also determined a safe limit for fish handling and investigated the length and weight gain variations. We found that an increase in AET affects fish survival and that the limit of handling time for this species was $546 \mathrm{~s}$; after this threshold, the individual probability of death exceeds 5\%. The length and weight gain of CR fish did not differ significantly from the control fish. We believe that CR is efficient for S. brasiliensis because it does not significantly impair their organic growth and causes little or no mortality if handling is performed properly; thus, it could be employed to assist conservation programs.
\end{abstract}

Keywords: recreational fishing, handling, air exposure, fish survival, conservation.

\section{A influência do pesque e solte na mortalidade de Salminus brasiliensis} (Cuvier, 1816)

\section{Resumo}

O pesque e solte (PS) tem sido utilizado para auxiliar programas de manejo que buscam promover a conservação e recuperação de estoques de peixes esportivos, através da redução da mortalidade pela pesca. Entretanto, sem a manipulação adequada dos peixes, essa atividade pode causar injúrias nos indivíduos, causando mortalidade. Dessa maneira, o PS deve ser permitido sob circunstâncias que possam garantir altas taxas de sobrevivência, de modo que as metas das medidas de conservação sejam atingidas. Assim, testamos experimentalmente os efeitos do PS sobre o dourado (Salminus brasiliensis), através da comparação de peixes capturados e liberados (peixes de PS) com peixes não capturados (peixes de controle) em um tanque de cultivo. Estimamos as taxas de mortalidades individuais relacionadas a sete tempos de exposição ao ar (TEA: 120 s, 240 s, 360 s, 480 s, 600 s, 720 s e 840 s). Determinamos um limite seguro para a manipulação do peixe e investigamos as variações no ganho de comprimento e peso. Foi encontrado que o aumento no TEA afetou a sobrevivência do peixe e que o limite de tempo para a manipulação da espécie foi de $546 \mathrm{~s}$; depois desse limite, a probabilidade individual de morte excede 5\%. O ganho de comprimento e peso dos peixes de PS não diferiu significativamente dos peixes de controle. Acreditamos que o PS é eficiente para o S. brasiliensis porque não afeta significativamente seu crescimento orgânico e causa pouca ou nenhuma mortalidade se a manipulação for realizada corretamente. Concluímos que a atividade pode ser empregada para auxiliar programas de conservação.

Palavras-chave: pesca esportiva, manipulação, exposição ao ar, sobrevivência do peixe, conservação. 


\section{Introduction}

The need for fishery resources conservation is urgent, as fishing activities can lead to overfishing of freshwater fish stocks (Allan et al., 2005). Historically, the main actions related to fishing and fish stocks management in Brazilian reservoirs, such as fishery control, stocking programs and fish passage system construction in hydroelectric reservoirs, were mostly unsuccessful or caused negative impacts (Agostinho et al., 2008). Thus, the development of aquatic resources management techniques and the improvement of existing measures are fundamental for conserving fish stocks in continental aquatic ecosystems (Agostinho et al., 2005). In this context, recreational fishery management also deserves attention because inadequate management can further aggravate the situation of exploited fish populations (Albano and Vasconcelos, 2013).

Aiming to assist the recovery of depleted fish stocks in both freshwater and oceanic environments, catch-andrelease (CR) angling has been used by the environmental agencies of many countries as a useful management tool for recreational fishery resources (Muoneke and Childress, 1994; Wilde, 1998; Lucy and Studholme, 2002; Bartholomew and Bohnsack, 2005; Cooke and Schramm, 2007; Cooke et al., 2013). However, the effectiveness of such management programs depends on the achievement of high survival rates and minimization of the negative consequences to fish health after their release (Cooke et al., 2002; Cooke and Suski, 2005). For this reason, specific research for each fish species, its geographic region, handling applied and equipment used are needed (Bartholomew and Bohnsack, 2005; Marques et al., 2007; Arlinghaus et al., 2010).

Recently, in Brazil, some state managers have implemented management programs that aim to recover fish populations, in which the only fishing activity allowed for designated species is CR. However, these conservation measures frequently are employed without an understanding of how angling actually influences the fate of the released fish (Arlinghaus et al., 2007; Cooke and Schramm, 2007). The impacts of CR on Brazilian game fish species are still not well understood and, in some cases, can lead to fish mortality, as well as to sublethal disturbances (Chaves and Freire, 2012; Petrere, 2014; Lennox et al., 2015), such as physiological disorders, behavioral alterations, and growth deficiencies (Cooke et al., 2002; Cooke and Suski, 2005).

As the stocks of dourado (Salminus brasiliensis) have shown a marked decline in some of their original hydrographic basins (Rosa and Lima, 2008) in the States of Paraná (Paraná, 2018) and Mato Grosso do Sul (Mato Grosso do Sul, 2019), commercial fishing was prohibited, and only CR was allowed for these stocks. In Argentina, Gagne et al. (2017) observed that air exposure for this species for long periods during CR can cause sublethal effects, such as stress and reflex impairments. To investigate the fate of the fish after release and with the assumption that CR angling is an applicable measure to assist in the conservation of $S$. brasiliensis, in this study, we experimentally evaluated the effects of CR on this species. To achieve this goal, we performed an experiment comparing caught and released fish (CR fish) with uncaught fish (control fish), estimated individual mortality related to seven air exposure times, determined a safe limit, and investigated the length and weight gain variations of the fish.

\section{Material and Methods}

\subsection{Study site and fish origin}

This study was approved by the Ethical Committee of Animals Use of the Western Paraná State University UNIOESTE, under protocol number 37/13. To conduct this catch-and-release (CR) study, 500 juveniles (ca. $5 \mathrm{~cm}$ total length per fish) of $S$. brasiliensis were acquired from a fish farm in Toledo, State of Paraná, Brazil, and translocated to the Environmental Aquaculture Research Institute (InPAA - UNIOESTE), located in the same city. In the InPAA, these specimens were stored in a $1600 \mathrm{~m}^{2}$ pond, fed with a mix of commercial fish food ( $42 \%$ protein) and juvenile fish (part of the natural diet (Flora et al., 2010)) for ten months, until they reached approximately $25 \mathrm{~cm}$ of their standard length (SL). After this period, 287 individuals were available to be used in the CR experiment (Figure 1).

\subsection{Experimental design}

To conduct the experiment, all available fish were: 1) caught from the pond with a fish net, anesthetized with benzocaine, the standard length was measured (SL) with an ictiometer and weighed (Wt) with a scale of one gram precision; 2) submitted to a surgical process to implant a passive integrated transponder (PIT) next to the dorsal fin; and 3) released and maintained in an $800 \mathrm{~m}^{2}$ pond for 30 days to observe possible mortality due to the surgical procedure, as recommended by Jensen et al. (2010) to avoid confusion with mortality due to proper CR activities (Figure 1). As recommended by Pollock and Pine (2007), all fish used during the experiment were kept in the same pond to simulate the $\mathrm{CR}$ process that occurs in the natural environment.

After 30 days of observation, the experimental CR was carried out for four weeks. For this effort, two days of fishing and five days without fishing were alternated to simulate the frequent behavior of sport fishers (fishing on the weekends). For the fishing days, the fishing took place for $3 \mathrm{~h}$ in the morning and $3 \mathrm{~h}$ in the afternoon. For each individual fish caught, the following protocol was adopted: obtaining the time between hooking and apparent exhaustion of the fish (playing time - PT); fish were landed with a lip gripper device; identification by PIT; measurement of SL; weighing of Wt.; atmospheric air exposure for a predetermined time (AET); and maintenance in the pond water during a minute for recovery followed by release back into the pond.

CR was performed following the recommendations of Ceccarelli et al. (2006). Tackle used to fish were rods with baitcasting or spinning reels for light and ultralight fishing, employing live bait and artificial lures. For live bait fishing, a "J" style hook with a total length of $2.5 \mathrm{~cm}$ and a needle 


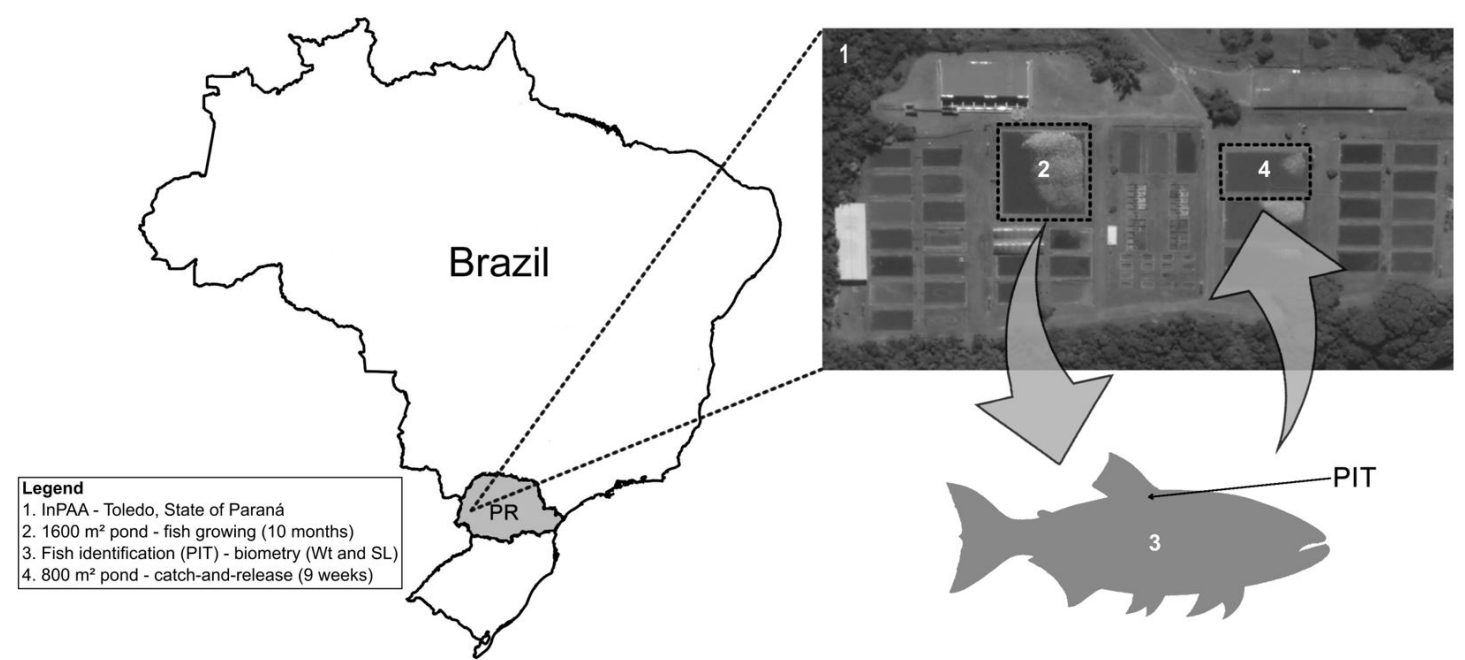

Figure 1. Study site and general experimental overview. Instituto de Pesca em Aquicultura Ambiental (InPAA) in Toledo, State of Paraná; $1600 \mathrm{~m}^{2}$ pond in which fish were raised for 10 months; fish identification by Passive Integrate Transponder (PIT), standard length and weight measuring; $800 \mathrm{~m}^{2}$ pond in which fish were kept for 30 days (four weeks) to climatization and posterior performance of experimental catch-and-release for 30 days (four weeks) and seven days (one week) for mortality observation after the catch-and-release period.

point with a barb, connected to a stainless-steel leader of $2 \mathrm{~cm}$ was used. The artificial lures used were spinners and small plugs equipped with barbed treble hooks.

The experiment had seven treatments of AET: $120 \mathrm{~s}$, $240 \mathrm{~s}, 360 \mathrm{~s}, 480 \mathrm{~s}, 600 \mathrm{~s}, 720 \mathrm{~s}$ and $840 \mathrm{~s}$. These times were determined after personal communications with sport fishers in the region. The individual fish for each treatment were selected from a systematic sampling in which the first fish caught was submitted to the first AET and following fish to successively longer times. The control group (C) consisted of fish kept in the same pond, but they were not caught during the catch-and-release period (sensu Pollock and Pine, 2007).

To observe long-term ( $>72 \mathrm{~h}$ ) mortality due to sublethal effects (Pollock and Pine, 2007), the experiment ended seven days after the CR period, when all fish were removed for biometry (SL and Wt.) and survival confirmation. During the entire experimental period, the pond was inspected daily for mortality observations. We also measured physical and chemical water variables daily, which remained in the acceptable ranges (temperature: 24.1 and $30.2^{\circ} \mathrm{C}$; dissolved oxygen: 9.8 and $13.85 \mathrm{Mg} / \mathrm{L}$; and $\mathrm{pH}$ : 8.71 and 9.17) for the survival and growth of tropical teleost freshwater fish (Baldisserotto, 2002).

\subsection{Data analysis}

Initially, we verified that the initial fish characteristics (SL and Wt.) and playing time (PT) were similar among the treatments of AET with a permutational multivariate analysis of variance (PERMANOVA; Anderson, 2001) of the standardized data $\left(\mathrm{F}_{(6,63)}=0.27, \mathrm{p}=0.99\right)$, which allowed us to perform the following analyses without considering these variables. In sequence, the length and weight gain were analyzed by the differences between initial and final biometric data, according to Equation 1:

$$
D S L=S L_{f}-S L_{i} \text { and } D W t=W t_{f}-W t_{i}
$$

in which $S L$ and $W t$. were the standard length and the weight on the last $(f)$ and first $(i)$ days of the experiment, respectively.

The assessment of the effects of AET on DSL and $D W t$ was performed by one-way analysis of variance (ANOVA) of the raw data (normality and homoscedasticity were determined with the Shapiro-Wilk and Bartlett tests, respectively, both under 5\% probability). As the $\mathrm{C}$ group contained more individuals than each AET treatment, we randomly selected individuals in the control group to balance the group sizes, allowing the application of ANOVA. For case of significant differences $(p<0.05)$ we used the post hoc Dunnett's test to contrast treatments with control group.

Mortality due to CR was measured by the model proposed by Pollock and Pine (2007), which considers the control group survival. In this model, the instantaneous mortality rate caused by hooks $\left(M_{H O}\right)$ is estimated by Equation 2:

$$
M_{H O}=-\ln \left(\frac{S_{H T}}{S_{C T}}\right)
$$

in which $S_{H T}$ is the survival of CR fish and $S_{C T}$ is the survival of control fish. As $M_{H O}$ represents the proportion ranging from zero, when all fish in the treatments survive, to one, when all die, we fit a logistic regression to the obtained instantaneous mortality rate over the AET. 

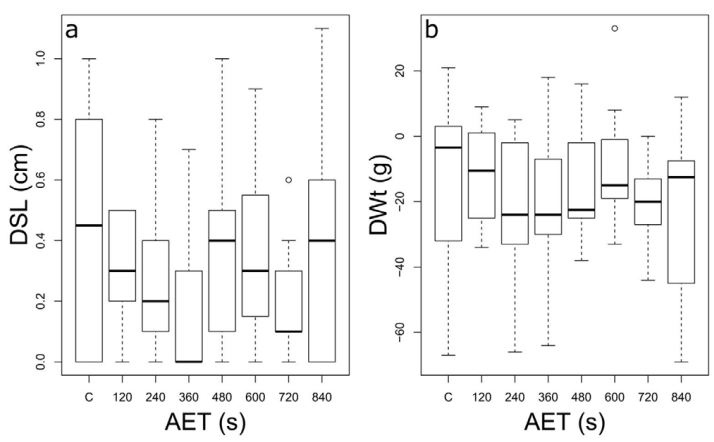

Figure 2. Box plot related to: (a) difference in standard length (DSL); (b) difference in weight gain (DWt) for air exposure times (AET).

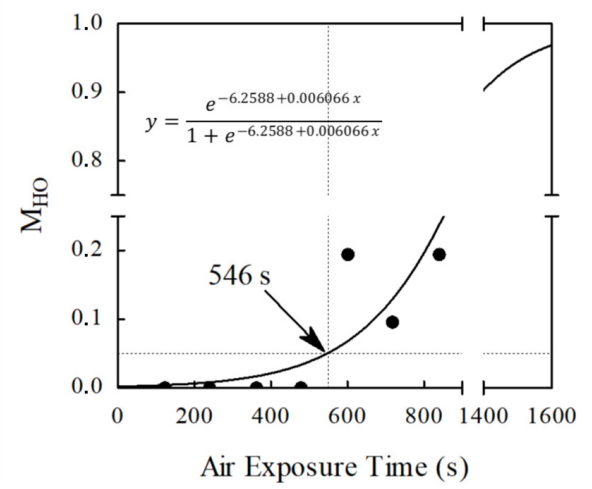

Figure 3. Instantaneous rates of catch-and-release mortality $\left(\mathrm{M}_{\mathrm{HO}}\right)$, adjusted logistic model equation, regression curve and critical limit of AET for $S$. brasiliensis.

We used the nonlinear Gauss-Newton estimation method and minimized the residual sum of squares (Davidon, 1991). We chose the logistic regression method because it gives a continuous equation for the individual probability for the occurrence of a determined event along a continuous variable (Neter et al., 1996); for this case, more fish die with increasing AET values. This procedure allowed us to estimate the specific value of AET that represents an individual risk of death equal to $5 \%$, the commonly used value in statistical significance tests.

PERMANOVA and ANOVA were performed with software R (R Development Core Team, 2017) and the logistic regression analysis was performed with Statistica 7.1 software (StatSoft, 2005) at the 5\% significance level.

\section{Results}

Following the experimental protocol, 70 individuals were caught and released (CR fish), with equally distributed values of AET. The treatments of AET did not affect the length and weight gain of fish (one-way ANOVA with treatments and control groups for $D L S: \mathrm{F}_{(7,65)}=0.85$, $\mathrm{p}=0.55$; and for $D W t: \mathrm{F}_{(7,65)}=0.57, \mathrm{p}=0.78$, respectively), so we did not apply the Dunnett's test. Although without distinct effects for AET and control, all groups showed a decrease in weight and an increase in length (Figure 2).

Of the 70 CR fish, five died (7.14\%), and of the 217 specimens in the control, only one died $(0.46 \%)$. The deaths in the AET treatments occurred from $600 \mathrm{~s}$ and longer, and all were observed within a short time (72 h after CR). The AET significantly affected the instantaneous mortality rate, $\mathrm{M}_{\mathrm{HO}}$, with increasing chance of death as the fish were exposed for longer periods to the air (logistic regression: final loss (Max likelihood) $=14.92$, $\left.\chi_{(I)}^{2}=6.186, \mathrm{p}=0.013\right)$. By the logistic model, it was estimated that $546 \mathrm{~s}$ the maximum AET allowed because above this period of time, the individual risk of fish death is higher than $5 \%$ (Figure 3 ).

\section{Discussion}

We carried out long-term observations and all deaths of $S$. brasiliensis in the AET treatments (7.14\%) occurred prior to $72 \mathrm{~h}$ after release and with more than $600 \mathrm{~s}$ of AET. The mortality rate of $S$. brasiliensis increased significantly with AET, as expected, and had already been reported for bluegill (Lepomis macrochirus) by Gingerich et al. (2007). These authors identified higher mortality rates in water at $27.4{ }^{\circ} \mathrm{C}$ and AET at 480 and $960 \mathrm{~s}$, close to the values observed for $S$. brasiliensis. In the present study, there was no mortality for AET shorter than $480 \mathrm{~s}$, and similar results were found for trout Salvelinus fontinalis (Schreer et al., 2005) and pikeperch Sander lucioperca (Arlinghaus and Hallermann, 2007). These studies did not find relevant mortality rates for AET less than $240 \mathrm{~s}$. However, both in Gingerich et al. (2007) and in our study, fish survival was affected when the fish were submitted to longer AET. Furthermore, Gagne et al. (2017), despite observed low mortality in S. brasiliensis due to CR, found that increases in AET induced stress and impaired reflexes of these fish, consistent with the idea that prolonged AET can influence fish welfare and health, leading to long recovery times and to mortality.

Other studies related to CR mortality performed in Brazil frequently show low percentages of immediate (soon after release) and short-term mortality $(<72 \mathrm{~h})$, supporting our results. Examining immediate mortality, Sepulchro et al. (2013) found 100\% survival of red piranha (Pygocentrus nattereri) for AET shorter than $180 \mathrm{~s}$. When related to short-term mortality, peacock bass (Cichla temensis) kept in a cage for $72 \mathrm{~h}$ after CR reported values of 3.5\% and $0.55 \%$ (Thomé-Souza et al., 2014; Barroco et al., 2018, respectively), $2.3 \%$ for C. orinocensis and 5.2\% for C. monoculus (Thomé-Souza et al., 2014). However, as these studies were carried out for short-term mortality evaluation, they were not able to quantify the effects of $\mathrm{CR}$ on weight and length gain.

The fact that the length and weight gain of the individuals submitted to the AET treatments had not been relative to the control suggests that CR did not exert a large influence on these gains during the experiment. These results support those found by Pope et al. (2007), in which differences in 
length and weight gain were not noticed between CR fish and control fish during a month of fishing and recovery. Arlinghaus and Hallermann (2007) also observed that growth was not significantly different among AET durations. However, Cooke et al. (2013), in a review study, reported that several CR studies had found some degree of sublethal disturbance due to catch and later release.

The determination of an AET limit, also termed as the critical AET, is fundamental for making the CR procedure more efficient for conservation purposes. Hooked fish undergo exhausting exercise during playing time, followed by air exposure time when the fish are handled before release. This procedure, if prolonged, may result in substantial physiological disturbances and tends to cause adverse impacts and generate longer recovery periods (Arlinghaus and Hallermann, 2007). Therefore, we can conclude that CR for $S$. brasiliensis should be practiced with AET less than $546 \mathrm{~s}$ to promote sustainable exploitation by recreational fishing. However, the handling time of fish out of water should be reduced as much as possible to ensure fish welfare from an ethical point of view. We believe that $\mathrm{CR}$ is applicable for this species because it does not significantly impair its organic growth and causes little or no mortality if handling is properly performed. Furthermore, future studies should focus on the relationship between CR for different aspects of fish biology, such as reproductive success.

\section{Acknowledgements}

This study was financed in part by the Coordenação de Aperfeiçoamento de Pessoal de Nível Superior - Brasil (CAPES) - Finance Code 001. We would like to thank CAPES for the scholarship they provided the first author during the master's program.

\section{References}

AGOstinho, A.A., PELICICE, F.M. and GOMES, L.C., 2008. Dams and the fish fauna of the Neotropical region: impacts and management related to diversity and fisheries. Brazilian Journal of Biology $=$ Revista Brasileira de Biologia, vol. 68, no. 4, suppl., pp. 1119-1132. http://dx.doi.org/10.1590/S151969842008000500019. PMid:19197482.

Agostinho, A.A., THOMAZ, S.M. and GOMES, L.C., 2005. Conservation of the biodiversity of Brazil's inland waters. Conservation Biology, vol. 19, no. 3, pp. 646-652. http://dx.doi. org/10.1111/j.1523-1739.2005.00701.x.

ALBANO, C.J. and VASCONCELOS, E.C., 2013. Análise de casos de pesca esportiva no Brasil e propostas de gestão ambiental para o setor. Revista Brasileira de Ciências Ambientais, no. 28, pp. 77-89.

ALlan, J.D., ABELl, R., HOGAN, Z., REVENGA, C., TAYLOR, B.W., WELCOMME, R.L. and WINEMILLER, K., 2005. Overfishing of inland waters. Bioscience, vol. 55, no. 12, pp. 1041-1051.http://dx.doi.org/10.1641/0006-3568(2005)055[1041:OO IW]2.0.CO;2.
ANDERSON, M.J., 2001. A new method for non-parametric multivariate analysis of variance. Austral Ecology, no. 26, pp. 32-46. http://dx.doi.org/10.1111/j.1442-9993.2001.01070.pp.x.

ARLINGHAUS, R. and HALLERMANN, J., 2007. Effects of air exposure on mortality and growth of undersized pikeperch, Sander lucioperca, at low water temperatures with implications for catch-and-release fishing. Fisheries Management and Ecology, vol. 14 , no. 2 , pp. $155-160$. http://dx.doi.org/10.1111/j.13652400.2007.00536.x.

ARLINGHAUS, R., COOKE, S. and COWX, I., 2010. Providing context to the global code of practice for recreational fisheries. Fisheries Management and Ecology, vol. 17, no. 2, pp. 146-156. http://dx.doi.org/10.1111/j.1365-2400.2009.00696.x.

ARLINGHAUS, R., COOKE, S.J., LYMAN, J., POLICANSKY, D., SCHWAB, A., SUSKI, C., SUTTON, S.G. and THORSTAD, E.B., 2007. Understanding the complexity of catch-and-release in recreational fishing: an integrative synthesis of global knowledge from historical, ethical social, and biological perspectives. Reviews in Fisheries Science, vol. 15, no. 1-2, pp. 75-167. http://dx.doi. org/10.1080/10641260601149432.

BALDISSEROTTO, B., 2002. Fisiologia de peixes aplicada ä piscicultura. Santa Maria: Editora UFSM, 212 p.

BARROCO, L.S.A., FREITAS, C.E.C. and LIMA, Á.C., 2018. Estimation of peacock bass (Cichla spp.) mortality rate during catch-release fishing employing different post-capture procedures. Brazilian Journal of Biology $=$ Revista Brasileira de Biologia, vol. 78, no. 2, pp. 195-201. http://dx.doi.org/10.1590/15196984.18915. PMid:28832842.

BARTHOLOMEW, A. and BOHNSACK, J.A., 2005. A review of catch-and-release angling mortality with implications for notake reserves. Reviews in Fish Biology and Fisheries, vol. 15, no. 1-2, pp. 129-154. http://dx.doi.org/10.1007/s11160-005-2175-1.

CECCARELli, P.S., CANTELMO, O.A., MELO, J.S.C. and BOCK, C.L., 2006. Pesque-e-solte: informações gerais e procedimentos práticos. Brasília: IBAMA, $42 \mathrm{p}$.

CHAVES, P. T. and FREIRE, K.M.F., 2012. A pesca esportiva e o pesque-e-solte: pesquisas recentes e recomendações para estudos no Brasil. Bioikos, vol. 26, no. 1, pp. 29-34.

COOKE, S.J. and SCHRAMM, H.L., 2007. Catch-and-release science and its application to conservation and management of recreational fisheries. Fisheries Management and Ecology, vol. 14, no. 2, pp. 73-79. http://dx.doi.org/10.1111/j.1365-2400.2007.00527.x.

COOKE, S.J. and SUSKI, C.D., 2005. Do we need species-specific guidelines for catch-and-release angling to conserve diverse fishery resources? Biodiversity and Conservation, vol. 14, no. 5, pp. 1195-1209. http://dx.doi.org/10.1007/s10531-004-7845-0.

COOKE, S.J., DONALDSON, M.R., O'CONNOR, C.M., RABY, G.D., ARLINGHAUS, R., DANYLCHUK, A.J., HANSON, K.C., HINCH, S.G., CLARK, T.D., PATTERSON, D.A. and SUSKI, C.D., 2013. The physiological consequences of catch-and-release angling: perspectives on experimental design, interpretation, extrapolation and relevance to stakeholders. Fisheries Management and Ecology, vol. 20, no. 2-3, pp. 268-287. http:// dx.doi.org/10.1111/j.1365-2400.2012.00867.x.

COOKE, S.J., SCHREER, J.F., DUNMALL, K.M. and PHILIPP, D.P., 2002. Strategies for quantifying sublethal effects of marine catch-and-release angling: insights from novel freshwater applications. American Fisheries Society Symposium, vol. 30, pp. 121-134. 
DAVIDON, W.C., 1991. Variable metric method for minimization. SIAM Journal on Optimization, vol. 1, no. 1, pp. 1-17. http:// dx.doi.org/10.1137/0801001.

FLORA, M.A.D., MASCHKE, F., FERREIRA, C.C. and PEDRON, F.A., 2010. Biologia e cultivo do dourado (Salminus brasiliensis). Acta Veterinaria Brasilica, vol. 4, no. 1, pp. 7-14. http://dx.doi.org/10.21708/avb.2010.4.1.1492.

GAGNE, O.T., OVITZ, K.L., GRIFFIN, L.P., BROWNSCOMBE, J.W., COOKE, S.J. and DANYLCHUK, A.J., 2017. Evaluating the consequences of catch-and-release recreational angling on golden dorado (Salminus brasiliensis) in Salta, Argentina. Fisheries Research, vol. 186, pp. 625-633. http://dx.doi.org/10.1016/j. fishres.2016.07.012.

GINGERICH, A.J., COOKE, S.J., HANSON, K.C., DONALDSON, M.R., HASLER, C.T., SUSKI, C.D. and ARLINGHAUS, R., 2007. Evaluation of the interactive effects of air exposure duration and water temperature on the condition and survival of angled and released fish. Fisheries Research, vol. 86, no. 2-3, pp. 169-178. http://dx.doi.org/10.1016/j.fishres.2007.06.002.

JENSEN, J.L.A., HALTTUNEN, E., THORSTAD, E.B., NÆSJE, T.F. and RIKARDSEN, A.H., 2010. Does catch-andrelease angling alter the migratory behaviour of Atlantic salmon? Fisheries Research, vol. 106, no. 3, pp. 550-554. http://dx.doi. org/10.1016/j.fishres.2010.08.013.

LENNOX, R.J., BROWNSCOMBE, J.W., COOKE, S.J., DANYLCHUK, A.J., MORO, P.S., SANCHES, E.A. and GARRONE-NETO, D., 2015. Evaluation of catch-and-release angling practices for the fat snook Centropomus parallelus in a Brazilian estuary. Ocean and Coastal Management, vol. 113, pp. 1-7. http://dx.doi.org/10.1016/j.ocecoaman.2015.05.005.

LUCY, J.A. and STUDHOLME, A.L., 2002. Catch and release in marine recreational fisheries. In: Proceedings of the 30th American Fisheries Society Symposium, 2002, Bethesda. Bethesda: American Fisheries Society, 250 p.

MARQUES, D.K.S., SILVA, R.A.M., LIMA, R.P., VARGAS, R.D. and PEREIRA, R.A.C., 2007 [viewed 10 June 2018]. Recomendações para praticar o pesque-e-solte [online]. Corumbá: Embrapa Pantanal. Available from: www.embrapa.br/busca-depublicacoes/-/publicacao/812413/recomendacoes-para-praticaro-pesque-e-solte

MATO GROSSO DO SUL, 2019. Lei $n^{\circ} 5.321$, de 10 de janeiro de 2019. Dispõe sobre a proibição da captura, do embarque, do transporte, da comercialização, do processamento e da industrialização da espécie Salminus brisiliensis ou Salminus maxillosus - Dourado. Diário Oficial do Estado do Mato Grosso do Sul, Campo Grande, 10 jan. p. 1.

MUONEKE, M.I. and CHILDRESS, W.M., 1994. Hooking mortality: a review for recreational fisheries. Reviews in Fisheries Science, vol. 2, no. 2, pp. 123-156. http://dx.doi. org/10.1080/10641269409388555.
NETER, J., KUTNER, M.H., NACHTSHEIM, C.J. and WASSERMAN, W., 1996. Applied linear statistical models. Chicago: Irwin, vol. 4, $318 \mathrm{p}$.

PARANÁ, 2018. Lei no 5.321, de 20 de dezembro de 2018. Dispõe sobre a proibição da captura, do embarque, do transporte, da comercialização, do processamento e da industrialização do peixe da espécie Salminus brasiliensis ou Salminus maxillosus, o Peixe Dourado. Diário Oficial do Estado do Paraná, Curitiba, 20 dez.

PETRERE, M., 2014. Pesque e solte: proteção ou dano para os peixes. Ciência Hoje, vol. 317, pp. 6-9.

POLLOCK, K.H. and PINE, W.E., 2007. The design and analysis of field studies to estimate catch-and-release mortality. Fisheries Management and Ecology, vol. 14, no. 2, pp. 123-130. http:// dx.doi.org/10.1111/j.1365-2400.2007.00532.x.

POPE, K.L., WILDE, G.R. and KNABE, D.W., 2007. Effect of catch-and-release angling on growth and survival of rainbow trout, Oncorhynchus mykiss. Fisheries Management and Ecology, vol. 14, no. 2, pp. 115-121. http://dx.doi.org/10.1111/j.13652400.2007.00531.x.

R DEVELOPMENT CORE TEAM, 2017. $R$ : a language and environment for statistical computing. Version 1.1.383. Vienna: R Foundation for Statistical Computing.

ROSA, R.S. and LIMA, F.C.T., 2008. Os peixes brasileiros ameaçados de extinção. In: INSTITUTO CHICO MENDES DE CONSERVAÇÃO DA BIODIVERSIDADE - ICMBio, ed. Livro vermelho da fauna brasileira ameaçada de extinção. Belo Horizonte: Fundação Biodiversitas, vol. 2, pp. 9-269.

SCHREER, J.F., RESCH, D.M., GATELY, M.L. and COOKE, S.J., 2005. Swimming performance of brook trout after simulated catch-and-release angling: looking for air exposure thresholds. North American Journal of Fisheries Management, vol. 25, no. 4, pp. 1513-1517. http://dx.doi.org/10.1577/M05-050.1.

SEPULCHRO, L.C.O., PITOL, D.N., DUCA, C., SANTOS, M.R. and GOMES, L.C., 2013. The stress response of red piranha (Pygocentrus nattereri (Kner, 1858)) to angling and air exposure. Journal of Applied Ichthyology, vol. 29, no. 4, pp. 916-917. http:// dx.doi.org/10.1111/jai.12121.

STATSOFT, 2005. Data analysis software system, version 7.1. Tulsa: Statsoft.

THOMÉ-SOUZA, M.J.F., MACEINA, M.J., FORSBERG, B.R., MARSHALL, B.G. and CARVALHO, A.L., 2014. Peacock bass mortality associated with catch-and-release sport fishing in the Negro River, Amazonas State, Brazil. Acta Amazonica, vol. 44, no. 4, pp. 527-532. http://dx.doi.org/10.1590/1809-4392201400193.

WILDE, G.R., 1998. Tournament-associated mortality in black bass. Fisheries, vol. 23, no. 10, pp. 12-22. http://dx.doi. org/10.1577/1548-8446(1998)023<0012:TMIBB >2.0.CO;2. 